\title{
A COMPARATIVE IMPACT OF CAUSE-RELATED MARKETING AND SPONSORSHIP LEVERAGED INTERNET DISPLAY ADVERTISING
}

\begin{abstract}
Cause-related marketing (CRM) and sponsorship activities have become an increasingly popular corporate social responsibility (CSR) strategy, whereby firms partner with nonprofit organisations (NPOs) to achieve varieties of business objectives, while still supporting NPOs' social causes. Advances in internet technology and e-commerce activities have facilitated the widespread use of internet CRM and sponsorship advertisement frames targeting potential donors and online customers. Typically, firms communicate through ads in variety of ways, such as offering a precise donation amount (PDA) to the charity organisation in question, or by declaring mutually beneficial collaboration of the firms' brand with the non-profit organisation (NPO),by stating an imprecise donation (IDA)offer. This study compares the effectiveness of PDA ads ( both at low and high donation amounts) with imprecise donation amount (IDA) internet display advertisement frames, in terms of attitude and purchase intention from a fundraising perspective. Using a web-based experimental survey design involving the national representative sample, the results of the ANCOVA analysis revealed that there is no significant difference in attitudes between precise and imprecise donation ad frames(PDA \& IPA). However, PDA advertisements were found to indicate higher purchase intention than the IDA ad frame; regardless of the perceived donation amounts were either low or high. Furthermore, PDA ads with higher donation amounts (versus low donation amount) engender greater purchase. This study contributes to the understanding of the effective use of cause-related and sponsorship internet ads, for consumer segmentation and targeting.
\end{abstract}

\section{KEY WORDS}

INTERNET, CAUSE-RELATED MARKETING, SPONSORSHIP, DISPLAY AD , DONATION AMOUNT

\subsection{INTRODUCTION}

The growth of e-commerce and internet technologies have provided online marketers with unprecedented opportunities to segment, profile, and target potential customers online. In the 
United Kingdom, online advertising expenditure has been growing for a decade, and it is estimated to reach $£ 24$ billion in 2019 , where $75 \%$ of the ads were attributed to display advertising (Advertising Association, 2018). There are varieties of ad frames, such as internet cause-related marketing (CRM) and sponsorship ads, that are often placed on nonprofit organisations' (NPOs) websites and webpages. The significant amount of attention dedicated to Internet advertising research is due to the varieties of available frames and the appeals they often have on Internet shoppers (Flores et al., 2014; Segev et al., 2014; Rieger et al., 2015; Bruce et al., 2017).

Internet CRM and sponsorship ads could generate funding for the worthy cause of an NPO; ,however, there is paucity of research that established the effectiveness of the ad . Advertising strategies hinged on the paradigm that product acquisition is driven by motivators that far exceed mere functionality and purpose; but includes customers' social, ideological and self-perceptions(Varadarajan and Menon 1988, Simmons, and Becker-Olsen, 2006; Arora, and Henderson, 2007; Koschate et al. 2012; Robinson et al. 2012). Until now, research has focused on ads presented in traditional media, such as magazines or in-store fixtures ( Lafferty et al. 2004; Liston-Heyes\& Liu, 2013; Müller et al., 2014; Kuo \& Rice, 2015). Unlike traditional ads, internet CRM and sponsorship ads can effectively focus on specific target markets and audiences. Internet ads are rarely directed at general audience. It is usually the consumer's responsibility to initiate and maintain contact with the marketer or NPO site. Moreover, advertising through internet media could be more readily scrutinized given the interactive, wide-reaching possibilities that the media presents. Internet CRM ad that offers a precise donation amount to an NPO's cause is referred to as PDA ad; while the sponsorship ad frame that does not specify the donation amount to an NPO's cause can be referred to imprecise donation amount(IDA) ad. The following review of literature outlines the conceptual foundation of CRM represented by PDA ads, and sponsorship framed as IDA; both of them represent internet devices for corporate giving.

\subsection{LITERATURE REVIEW AND CONCEPTUAL FRAMEWORK}

\subsection{Conceptualization of Cause-related marketing and Sponsorship}

A well-known conceptualization of CRM defines the advertising campaign as "a commercial activity by which business and NPO partner to market an image, product or service for mutual benefit." (Adkins, 1999, p.11). This marketing concept employs a transactional 
approach, whereby donation is given to the NPO when consumers purchase a CRM-branded product. In this perspective, Varadarajan and Menon (1988, p. 80) considered CRM to be "the process of formulating and implementing marketing activities that are characterized by an offer from the firm to contribute a specified amount to a designated cause[sic] when customers engage in revenue-providing exchanges that satisfy organisational and individual objectives". Transactional perspectives suggest that the donated amounts generated by CRM depends on the volume of the transactions. In the body of corporate social responsibility literature, advertising has also been found to focus on establishing the firms' image, awareness and reputation through cause sponsorship, such as CRM; which has been termed strategic philanthropy (Adkins, 1999; Daw, 2006).

Unlike CRM, sponsorship that involves the upfront provision of financial (or in-kind) to support the social cause of a firm, towards achieving its commercial objectives(Meenaghan 1983). It works by trying to establish a link in the minds of consumers, and a social cause to generate goodwill among consumers; which in turn improves consumers' attitudes towards the firm as well sales (Dean 2003; Andersen and Johansen, 2016). Usually, the association of a firm with a social cause occurs primarily through marketing; as Cornwell (1995) coined the termed "sponsorship-linked marketing", to describe the planning and execution of marketing activities to create brand awareness, generate consumer goodwill and enhance sales. As both advertising strategies leverage a firm's giving to social cause, and they present similarities and dissimilarities; it makes sense to compare their relative effectiveness especially on the internet where PDA and ad frames are widely used. Besides, advertisers would often consider either CRM or sponsorship when contemplating corporate giving among other philanthropic activities(Polonsky and Speed, 2001). This article thus presents the first study addressing the comparative research on CRM and sponsorship leveraged internet display advertising.

\subsection{Internet CRM and Sponsorship Ad Frames and The Perceived Donation Amount}

On the Internet, firms increasingly employ PDA and IDA advertising, to obtain customer goodwill, improve brand image and make sales. This can be more broadly considered as attitudinal change and purchase intention for the brand. However, because these efforts have direct implications for pricing strategy and firm profitability, understanding the relationship between the perceived donation amount variable and the expected outcomes is essential. 
Since CRM and sponsorship campaigns provide means for consumers to support NPO's cause with money that is supposed to be part of the firm's profit, acceptance of advertising seems to depend mainly on the perceived donation amount. In general, buyers evaluate higher donations more positively than smaller donations (Koschate-Fischer et al., 2012). Existing studies in traditional CRM and cause-sponsorship campaign have identified donation as a critical variable in such campaigns. They suggest that the perceived donation amount variable could trigger the self-serving or altruistic perception of the advertising when the donation is in small, medium and large amounts (Strahilevitz 1999; Pracejus and Olsen, 2003; Arora and Henderson, 2007; Chang, 2008; Muller et al., 2014). Smaller donations give the impression of exploiting consumers' and the NGO's giving instincts, by the company or seller. In line with the concept of impure altruism, a customer's donation utility in response to PDA ad frame should depend on the perceived donation amount, such that the higher donation levels provide more benefit, irrespective of whether the motive of the donation was altruistic or egoistic, (Andreoni 1989).

Examples of PDA include Tradecraft offering Christian Aid NPO 10\% of the sales of its products advertised on the NPO’s site; and the Little Good Company (LGC) donating $£ 0.07$ from every pack of sausages sold via its website to Christian Aid. These examples represent the PDA ad frame when the donation amount is precise. Still, IDA in sponsorship ad frame may show a simple declaration statement of sponsorship or association with a social cause in the ad, e.g. TruRating declares -"with donate" on its website. Thus, the use of Internet PDA and IDA ad placement on non-profit sites and Internet spaces present alternatives to traditional CRM and sponsorship advertising on the Internet, which warrants the understanding of how consumers view and response to them in terms of attitudes and purchase intention.

\subsection{Attitudes and Purchase Intention for PDA and IDA Ads}

The comparative impact of PDA and IDA ads is examined, in terms of attitudes and purchase intention of the consumers. Firstly, attitudes are consumers' evaluations of some component of the advertising, such as the perceived donation amount, after being exposed to the ad (Lafferty et al., 2004). This also includes the consumer's value judgement of the firm's contribution to a social cause or charity. The value judgements are based on consumers' collective evaluations of potential financial, social, and environmental contributions of the 
firm over time (Barnett et al., 2006). The variable, attitude towards an ad, is widely used to measure effectiveness of advertisements. This is because of the evaluative tendency of the features of an ad. It is noteworthy to state that attitudes could be learned, influenced, or modified; leading to behavioural change (Ajzen, 1991; Tutaj and Reijmersdal, 2012). Also, attitudes could surpass either positive or negative feelings toward the advertisement, but examines the integrity of the firm, which manifests in its image and credibility (Lafferty et al., 2016). In line with the persuasion knowledge model (Friedstad and Wright 1994) that explains the persuasiveness of advertising, this investigation proposes a conceptual model (Figure 1) to compare the relative impact of PDA and IDA ad frames with focus on perceived donation suggestive of the ads. Given the feeling of warm glow resulting from the purchase of a product or service by the consumer, to trigger the donation to social cause in PDA ads (Videras and Owen, 2006; Crumpler and Grossman, 2008); and the benefits of supporting IDA ad sponsors, which reveal some of the firm's profit. The relative attitudinal impact of the ads are examined by proposing the following hypotheses.

When exposed to advertising, consumers infer the motives of advertisers and engage in attributional interpretations of the ad's claims (Chingching, 2012). From the review in the preceding section, the major difference between perceptions of PDA and IDA ad frame stems from the higher possibility to simultaneously activate negative and positive attitudes towards the PDA, based on the perceived donation size. In contrast, IDA ads are more likely to enable positive attitudes since the information on minimal donation is not always provided. Recognising the ambivalence view of both the positive and negative attitudes of PDAs ads, this study aims not to only compare the relative impact of IDAs with PDAs ads, but to also examine the comparative effectiveness of the IDAs with PDAs at different donation amounts. Accordingly, the following hypotheses are investigated.

H1a: Consumers have a stronger positive attitude towards PDA (low) ad, than IDA ad as a fundraiser

H1b: Consumers have a stronger positive attitude towards PDA (high) ad, than IDA ad as a fundraiser

H1c: Consumers have a stronger positive attitude towards PDA (high) than PDA (low) ads. These propositions centre on the perceived donation as the principal ad design variable in the ad frames, where the amount is either low or high for PDA, or unidentifiable in IDA ad frames. 
Secondly, purchase intention provides one of the primary motives of an advertising campaign (Lafferty et al., 2016), which is critical to how consumers view and engage with the brand over time. Purchase intention is linked to financial outcomes, in form of income received by the firm through increased brand sales, which in turn leads to increased donation to the charity organisation through firms' donation or sponsorship. From an accounting perspective, the focus of the advertising campaign planning is to influence purchase intention, which has direct financial outcome, by providing concrete measure for evaluating the advertising success. The theory of planned behaviour affirmed that consumers' intentions to purchase a product in the future, predict the likelihood of the consumer performing that task (Ajzen, 1991). Hence, existing CRM research (e.g.Hajjat,.2003), and sponsorship research , as well as display advertising research (e.g. Hwang et al.,2011; Segev et al 2014) have commonly applied purchase intention to evaluate the effectiveness of the advertising. Building upon the proposition that ambivalent perceptions and firm's self-serving and altruistic motives, attributions are more likely to be activated by PDA ads, than by the IDA ads. This paper proposes the relations in Figure 1, and the following hypotheses:

Accordingly, this study investigates the relative impact of purchase intention for the ad frames, as depicted in Figure 1, by proposing that:

H2a: Consumers have a stronger purchase intention for PDA (low) than IDA ads. $\mathrm{H} 2 \mathrm{~b}$ : Consumers have a stronger purchase intention for PDA (high) than IDA ads. H2c: Consumers have a stronger purchase intention for PDA (high) than PDA (low) ads.

\section{INSERT FIGURE 1 ABOUT HERE}

\subsection{The Effect of Cause-Involvement}

The model features cause-involvement - an individual difference factor that might alter the perception of the ad. Evidence in CRM advertising suggests that behaviour towards CRM may not be dependent on the perceived donation amount in advertising, but also on several variables, including consumers' personal involvement with the NPO's cause. That is, causes that revolve around personal relevance and intrinsic importance (Petty et al., 1983, Kotler et al., 2012). Examples include disaster responses and children's causes, which could likely 
generate more supportive cause in CRM, than the other types of causes (Ellen and Webb, 1996; Ross, 1992; Hajjat, 2003). Similarly, online advertising research suggests that involvement plays significant role in moderating and interpreting variable relationships (Muehling et al., 1993; Belch et al., 2008).This affects the level of arousal, and preparedness to respond to advertising. Thus, to make a more accurate comparison of the ad frames, consumers' involvement with children's NPO is evaluated as a covariate in the model

\section{O METHODOLOGY}

\subsection{Study Design}

The design was a three-Ad frame, one-factor, between-subjects design that allowed participants to be randomly assigned to evaluate one of the three ads frames(PDA(low), PDA(high) and IDA). The Ads were selected based on a pre-test, as discussed in the next section. Participants assessed the Ad offer and completed a measure of Attitude towards the advertising and Purchase Intention. The design thus enables the research to quantify and compare consumers' response towards the Ads frames. Also, the design allowed for the control of cause-involvement variable that could confound values of the dependent variables, because of the independent variable of interest (ad frames perceived donation). For the analysis, a one-way between-subjects ANCOVA analysis procedure provided the best method to compare attitudes towards Ad frames as well as Purchase Intention, with Cause-Involvement as the covariate(Judd et al., 2009; Wilcox, 2012; Laerd, 2018).

\subsection{Stimuli and Pre-tests}

While developing the study stimuli, it was necessary to select a company/product and a non-profit (NPO's) cause that is acceptable to participants, in an attempt to gain a greater level of engagement with the study (e.g. Koschate et al., 2012). Also, participants should typically prefer to buy the product online; otherwise, it would not be possible to fully assess the effect of internet ads on consumers' behaviour. It was discovered that flight tickets were frequently bought online among a pre-test sample of nine respondents. In terms of the specific company, the sample indicated British Airways as a popular company (among three others presented); thus, it was selected for the study. The sample revealed that Save The Children (among three others presented) is a well-known NPO dealing with children's issues, and it was selected as the NPO beneficiary of the advertising donation. The NPO site hosted the display ad which is hyperlinked to the landing website page of the company (Appendix 1a). 
The perceived donation amount was manipulated from a $1 \%$ to a $10 \%$ (representing a low and a high donation amount) for the 2 PDA ad frames. This was consistent with previous studies that investigated the effect of donation amounts in traditional CRM (Pracejus and Olsen, 2003; Pracejus and Olsen, 2004; Koschate et al., 2012; Moosmayer and Fuljahn, 2013), from observation of real flight ticket promotion. For the IDA ad, three NPO support-related phrases were tested with nine pre-test respondents to identify the one that best suggests the company's monetary contribution to the NPO, albeit imprecisely. The statements included: "proud to support the vulnerable" and "save the children" and "We Care". The phrase "We Care" was found to be the best option to use in the study (see Appendix 1b).

\subsection{Sampling and Procedure}

The study employed a professional online survey agency that provided the national (UK) databases of consumers for the study. A total of 550 UK-based participants were recruited and incentivised with e-vouchers through Marketest System; a reputable market survey firm with a UK-based consumer participant pool. The nationally representative sample was chosen so that a diverse demographic could provide results that were more generalisable to the adult consumer population. Of the 550 participants, 12 were excluded, as they did not seem to be engaging with completing the survey; thus, resulting in a final total participants sample of 538.

The results of the demographic analyses for participants $(n=538)$ profile showed that there were fairly equal number of males $(48.7 \%, \mathrm{n}=268)$ and females $(51.3 \%, \mathrm{n}=276)$ participants. These were distributed randomly and equally across the experimental ad conditions. Educationally, there were participants below graduate level included $(51.3 \%$, $\mathrm{n}=276)$ and graduate level $(40 \%, \mathrm{n}=214)$. The postgraduate level $(9 \% ; n=48)$ participants accounted for less significant part of overall study participants. Most of the participants $(74.4 \% ; n=400)$ spent above six hours per week on the internet; while most of them $(75 \%$, $\mathrm{n}=403$ ) bought a flight ticket online within the last two-years. Furthermore, they also shopped online for other products; at least five times in the last two years $(88 \%, n=462)$. Therefore, the study participants were versed and knowledgeable with the processes of internet shopping, in a bid to exhibit typical behaviour under the experimental options presented in this study. 
The experimental survey design and data collection process complied with the authors' institutional research ethical standards and safety monitoring. Participants were randomly assigned to one of the three experimental scenarios relating to sample photos of three display ad conditions: PDA of 1\%, PDA of $10 \%$ and IDA (no \% of donation) display. After viewing an advert, the participants were asked questions including their attitudes, purchase intentions and cause-involvement to generate the data.

\subsection{Operationalization and Measurement of Variables}

The conceptual framework (Figure 1) depicts two independent variables: (i) the perceived donation size (linked to the three ad frames) and (ii) cause-involvement (a covariate); and two dependent variables: attitudes and purchase intention. These are explained and measured using established scales from prior studies as follows.

First, the key variable of interest in the ads is operationalised as "the perceived donation amount", which refers to consumers' assessment and discernment of the potential benefit of advertising to the NPO's cause financially per each of the ad frames. It was measured by a 2item, 7-point Likert scale implemented in similar studies in the traditional CRM contexts (e.g. Koschate-Fischer et al., 2012). However, a third item was included to the scale, which resulted in a strong convergent validity with the original 2 -item scale. The scale assesses consumers' predispositions to respond in a consistent way, regarding their perception of the perceived donation that provides financial feedback for each of the ads. The final 3-item scale, detailed in Appendix 2, achieved a Cronbach's value of 0.95, which is higher than the recommended threshold of 0.70 (Nunnally, 1978). Focusing on the perceived donation amount as the principal variable and indicator of differences for the design of the ad frames; internal validity for the study was established. That is, the impact this variable on the dependent variables could be explained mostly by this. The manipulation of instructions is one of the basic techniques used in creating variation in the independent variable (Christensen, 2007). For this reason, the instructions to the participant groups accompanying the ad frames were kept brief, regarding the perceived contribution of the ad to the NPO and their attitude and purchase intention.

Second, attitudes towards the ad, as discussed earlier, was assessed by adapting a 4-item, 7point Likert scale developed by Mackenzie and Lutz (1986). The scale yielded $\alpha=0.91$. 
Third, purchase intention, which is linked to financial feedback of buying the ad offer. It was measured by a 4-item, 7-point Likert scale developed by Yi (1993), resulting in $\alpha=0.90$ as detailed in Appendix 2. Finally, Cause-Involvement, referring to the personal relevance or importance of the NPO's cause associated with the ads, was operationalised as a covariate. It was necessary to minimise the potential confounding effect of this variable, being consistent with the Elaboration Likelihood Model (Petty et al., 1983). The theory suggests that when consumers are more involved with a cause (versus less interested), the ad would be more diligently processed; hence, making a more significant impact on the dependent variables of interest. The variable was measured by a 3-item (Grau and Folse, 2007), 7-point Likert scale as detailed in Appendix 2. The measure yielded a Cronbach's value of 0.93.

\subsection{Model Pre-test}

The model data was pre-tested to ensure the relationships meet the essential requirements for ANCOVA analysis (Laerd Statistics, 2018). The analysis indicated a linear relationship between involvement (covariate) and the dependent variables (attitude and purchase intention) for each ad group, as assessed by visual inspection of scatterplots. There was homogeneity of regression slopes as determined by comparison between the two-way ANCOVA models, with and without interaction terms. There was homoscedasticity within groups, as assessed by visual inspection of the studentised residuals plotted against the predicted values for each group; and variances were homogeneous, as assessed by Levine's test of homogeneity of variance. There were no outliers in the data, as assessed by no cases with Student's residuals higher than \pm 3 standard deviations. There were also no leverage or influential points, as assessed by leverage values and Cook's distance, respectively. Studentised residuals were normally distributed, as assessed by Shapiro-Wilk's test ( $\mathrm{p}>0.05)$. Thus, our data satisfied the requirements to conduct ANCOVA (Laerd Statistics, 2018).

\subsection{Manipulation Check}

The donation amount for the PDA ad frames was verified by asking participants to rate their perception for $1 \%$ and $10 \%$ donation amount for PDA(low) and PDA(high) ads frame, respectively. A three-statement, seven-point scale(Koschate et al. 2012) was provided for the rating as detailed in the appendix $1 \mathrm{c}$. The scale was found reliable $(\alpha=.87)$. An independent t-test analysis procedure indicated that participants in the PDA(high) $(\mathrm{M}=5.312, S D=0.907)$ rated PDA(high), significantly higher than participants in the PDA(low) ads condition (M 
$=2.915, S D=0.829)$. A statistically significant difference of $2.40(95 \% \mathrm{CI}, 2.218$ to $2.574), t(362.376)=26.441, p=.0005$. Therefore, the PDA ad type manipulation worked as intended. It was unnecessary to test for the perceived donation amount for the IDA ad; because unlike the PDA ads, the IDA does not specify the donation amount.

\subsection{HYPOTHESES TESTING RESULTS AND DISCUSSION}

Analysis of covariance was first carried out to test hypotheses; for attitudes towards the ads and then purchase intention for the ads after controlling for causeinvolvement. Results for these analyses are presented in Table 1

\section{INSERT TABLE 1 ABOUT HERE}

\subsection{Attitudes towards the Ads}

Firstly, analysis of covariance (ANCOVA) was conducted with attitude, towards the ad as the dependent variable and the perceived ad donation amount for the ad as the independent variable. After adjusting for the covariate (cause involvement), the means for attitudes towards the ad frames(M IDA=5.033 SE=.083; $\mathrm{M} P D A(l o w)=5.161$, $\mathrm{SD}=0.079$; $\mathrm{M}$ PDA (high) $=\mathrm{M}=5.188, \mathrm{SD}=0.079$; see Figure 2), were almost equal. The ANCOVA did not reveal any significant main effect for attitudes of the ads, $\mathrm{F}(2$, $538)=1.023, p=0.360$ partial $\eta 2=0.004$. Accordingly, results of follow-up contrast analysis for attitude of the ads showed the operation unnecessary(Laerd Statistics 2018; Hsu, 1996). These results are summarized in Table 1. Overall, the results showed that H1a, H1b and H1c were not supported.

\section{INSERT FIGURE 2 ABOUT HERE}

\subsection{Purchase Intention towards the Ad}

Secondly, analysis of Covariance (ANCOVA) was also conducted, but with purchase intention for the ad, as the dependent variable and the perceived ad donation amount to the independent variable. After the adjustment for covariate, there was statistically significant difference in purchase intention between the ad frames, $F(2,534)=22.186, p<0.0005$, partial $\eta 2=0.077$. Accordingly, follow-up contrast analyses with Bonferroni adjustment, using the full dataset showed that mean Purchase intention for the ads (M IDA=3.65 SE=0.083; M 
$\operatorname{PDA}($ low $)=4.23, \mathrm{SE}=0.10 ; \mathrm{M} \mathrm{PDA}$ (high) $==4.60, \mathrm{SE}=0.10$; see Figure 3 ), was significantly greater in PDA(low) vs. the IDA ad frame (mean difference of $0.578(95 \% \mathrm{CI}, 0.235$ to 0.922), $\mathrm{p}<0.0005$ ); also significantly greater for PDA(high) vs. IDA (mean difference of 0.947 (95\% CI, 0.604 to 1.290), p <0 .0005). Finally, purchase intention was also greater for PDA (high) vs. PDA (low) (mean difference of 0.368(95\%CI, 0.034 to 0.703 ), $\mathrm{p}=0.025$ ).

These results are detailed in Table 2 and depicted in Figure 3; thus, showing that hypotheses $\mathrm{H} 2 \mathrm{a}, \mathrm{H} 2 \mathrm{~b}$ and $\mathrm{H} 2 \mathrm{c}$ were supported.

\section{INSERT FIGURE 3 ABOUT HERE}

\subsection{Discussion}

Internet CRM and sponsorship provides an unprecedented opportunity for firms to partner with NPOs' causes over the internet, towards attaining social and financial benefits. No extant literature directly compares consumers' positive and negative perceptions of CRM and sponsorship ads frame on the Internet; nor have it contrasted how consumers respond to them, even though they are widely used advertising strategies.

In comparison to traditional CRM and sponsorship on the Internet, these ads could generate less scepticism of the advertising, given that the ads are accessible based on the internet search behaviour, interest, sites subscriptions and the operation of personalisation and targeting algorithms. Moreover, advertising on Internet media could be more readily scrutinised given the interactive and the wide-reaching possibilities presented by online media. Also, as brand alliance with social causes has become a common marketing strategy (Kotler et al., 2012 ) with a mixed understanding of how best to design the advertising. The results of the current study should provide an insight into the nature of the factors which influence consumers' behaviour. Specifically, it provides internet marketing researchers with theoretical insight, and it guides advertisers on the relative effectiveness of cause-related marketing and sponsorship ad frames.

Past researches have extensively applied attitude to understanding consumers' response to advertising, indicating brand image and reputation. The current study did not find a significant difference in attitudes towards the three ad frames. The study acknowledges the findings of Koschate et al. (2012) and Muller et al. (2014), in a traditional offline context that shows larger donation amounts in CRM advertising, as this engenders more positive attitudes towards the campaign and brand. Although a limited number of such studies showed a 
negative effect on brand evaluation (Chang, 2008; 2012). The current study contradicts the positive results of attitudinal feedback, based on the perceived donation size in the advertising. Also, the study showed that Internet ads with precise donation (PDA) to an NPO's cause showed higher purchase intention than IDA ad; irrespective of whether the donation is small or in substantial amount (i.e. $1 \%$ or $10 \%$ ). These results aligned with the findings in traditional CRM campaign, which suggested that when advertising indicates the actual amount donated to NPO's cause per purchase, the likelihood of viewing the campaign positively tends to increase" (Human \& Terblanche, 2012, p. 143; Hyllegard et al., 2010). Koschate et al. (2012) and Muller et al. (2014) highlighted that CRM's claims are more persuasive when the donation size is significant. With no precision as to the level of contribution via the IDA ad frame, consumers would be more sceptical of the brand's motives when processing the merit of IDA, relative to PDA ad to make a purchase.

The affective and cognitive paradigm is offered to explain the null difference in attitudes, towards the ads hypotheses and the expected positive results in purchase intention hypotheses. Both cognitive and affective responses are involved in forming attitudes towards the ad(Zajonc and Markus, 1982; Hwang et al. 2011). Given that consumers are generally supportive of brands that identify with a social cause (Cone, 2019). Emotional attitudinal responses are exhibited whenever consumers discover what a brand socially stands for; irrespective of how limited or elaborate their actions may be. Hence, the null difference in attitudes towards the PDAs and IDA ad frames(H1a-H1c). This further explains brands progressively incorporate CRM and sponsorship in their marketing activities.

By contrast, purchase intention elicits not only affective processing of the appeal, but much more of the cognitive assessment of merits of the ad; especially the internet context that provides greater interactivity, quick-access to customer preference and more elaborative in making an informed purchase decision. Accordingly, the cognitive assessment of the benefit (donation amount) supplied via the ad's frames could account for the stronger purchase intent for the PDAs versus IDAs. The results highlighted the importance of the concept of perceived personal contribution, which aligns with the literature in prosocial behaviour (Robinson et al. 2012). This suggests that consumers are more motivated to personally contribute to a cause where supporting the advertising triggers higher donations to the cause. The present study also contributes to the attitude-intention gap phenomenon, especially in socially responsible and ethical consumerism; demonstrating that positive attitudes do not always translate to 
behavioural intentions (Carrington et al., 2010; Carrigan and Attalla, 2001; Antonetti and Maklan, 2015).

\subsection{Implications}

The findings also provide important practical implications on consumers' evaluation and feedback to Internet CRM, as well as sponsorship advertising, both socially and financially, in terms of attitudes and purchase intention, respectively.

Internet marketers are being challenged to differentiate their products in an increasingly competitive marketplace; develop financially accountable advertising programs; and accommodate consumer pressure for socially responsible behaviour. Also, increased competition has called for the need to evaluate traditional advertising strategies, such as CRM on the internet marketplace. The findings indicate that improving attitudes towards the brand is a social brand benefit that could alter the image and reputation of the brand without significant financial input. A clear demonstration of association with an NPO's cause could achieve an improved image and reputation. However, when it comes to translating attitudes to purchase behaviour in short term, there is an expectation for brands to demonstrate corporate social responsibility in the Internet CRM and sponsorship advertising, by providing significant donation amounts to NPO's cause. With this approach, marketers can avoid the risk of being perceived as exploitive to NPO's cause or customers' giving nature. Higher donations create more benefits for customers in strengthening the perception of personal role in contributing to the non-profit's cause and creating a socially responsible warm feeling for consumers. This in turn should lead to a higher intention to purchase. An awareness of the findings is presented in this article should help marketers in developing effective Internet CRM and sponsorship campaign strategy.

\subsection{Limitations and future research}

This paper has highlighted the relative impact of CRM and sponsorship strategies used in leveraging the display ad. This work represents the beginning of research on Internet $\mathrm{CRM}$, and there is a need to embark on more research to examine the whole range of issues involved. An examination of the impact of internet CRM and sponsorship ads needs to consider the range of potential moderator variables, such as cause-involvement, perceived sincerity of the advertising. Another limitation of the study could be related to the use of real brands (Save the Children and British Airways), which was intended to strengthen the external validity of the study design, but also posed threats to internal 
validity, due to the participants' familiarity with those brands and both brands are known to be involved in CRM campaigns. In addition, an airline ticket is a high-priced item that may make consumers inclined to support CRM to counterbalance the guilt of spending so much money on the ticket. However, a flight ticket is a product that is more often purchased online than low-priced fast-moving consumer products. Thus, it is particularly relevant to this study. Further research could compare the effectiveness of the ad from the perspective of the company or commercial partner, by embedding the ad in the company's website instead of the NPO's website. Further studies may also examine click-through rates (CTR) and conversion rates, instead of attitudes and purchase intention used in this study. Although our approach made comparisons with existing studies in the traditional CRM context easier 


\section{REFERENCES}

Adkins, S. (1999) Cause-related marketing: who cares wins? Oxford: Butterworth Heinemann.

Advertising Association (AA) (2018) 'AA/WarcAdspend Figures Q1. 2018: UK Internet Adspend'. Available from: https://www.adassoc.org.uk/2018/07/uk-advertisingspend- achieves-record-for-q1-2018/ (Accessed 12 March 2020).

Ajzen, I. (1991) 'The theory of planned behaviour: Organizational behaviour and human decision processes', 50(2), pp.179-211.

Andersen, S.E., and Johansen, T.S. (2016) 'Cause-related marketing 2.0: Connection, collaboration and commitment', Journal of Marketing Communications, 22(5), pp.524-543.

Andreoni, J. (1989), "Giving with Impure Altruism: Applications to Charity and Ricardian Equivalence,” Journal of Political Economy, 97 (6), pp.1447-58.

Antonetti, P. and Maklan, S. (2015) 'How categorisation shapes the attitude-behaviour gap in responsible consumption', International Journal of Market Research, 57(1), pp.51-72.

Arora, N. and Henderson, T. (2007) 'Embedded premium promotion: why it works and how to make it more effective', Marketing Science 26, (4), pp.514-531.

Barnett, M., Jermier, J.M., \& Lafferty, B. A. (2006). Corporate reputation: The definitional landscape. Corporate Reputation Review, 9, pp.26-38.

Belch, G. E. and Belch, M. A. (2008) Advertising and promotion : an integrated marketing communications perspective. 8Th int. student edn. Maidenhead: McGraw-Hill.

Bruce, N. I., Murthi, B.P.S. and Rao, R.C. (2017) 'A dynamic model for Internet advertising: the effects of creative frame, message content, and targeting on engagement', Journal of Marketing Research (JMR), 54(2), pp.202-218.

Carrigan, M. and Attalla, A. (2001) 'The myth of the ethical consumer: do ethics matter in purchase behaviour?' Journal of Consumer Marketing, 18, pp.560-578.

Carrington, M.J., Neville, B. and Whitwell, G. (2010) 'Why ethical consumers don't walk their talk: towards a framework for understanding the gap between the ethical purchase intentions and actual buying behaviour of ethically minded consumers'. Journal of Business Ethics, 97, pp.139-158.

Chang, C., (2012). The effectiveness of advertising that leverages sponsorship and causerelated marketing: A contingency model. International Journal of Advertising,31 (3), pp.317-338.

Chang, C.-T. (2008) 'To donate or not to donate? Product characteristics and framing effects of cause-related marketing on consumer purchase behavior', Psychology \& Marketing, 25(12), pp.1089-1110. 
Chang, C.-T., (2008). To donate or not to donate? Product characteristics and framing effects of cause-related marketing on consumer purchase behaviour. Psychology \& Marketing,25 (12), pp1089-1110.

Chingching C. (2012) The effectiveness of advertising that leveragessponsorship and cause-related marketing, International Journal of Advertising, 31(2), pp.317-338

Christensen,L.B.(2007)ExperimentalMethodology, $10^{\text {th }}$ ed. Pearson.

Cone, 2019. 2019 Porter Novelli/Cone Purpose Biometrics Study https://www.conecomm.com/research: Accessed 23/06/2020]

Cornwell, T.B. (1995) Sponsorship-linked marketing development. Sport Marketing Quarterly, 4(4), pp.13-24

Crumpler, Heidi and Philip J. Grossman (2008), “An Experimental Test of Warm Glow Giving, ” Journal of Public Economics, 92 (5/6), 1011-1021.

Daw, J. (2006) Cause-marketing for non-profits : partner for purpose, passion, and profits. Hoboken, N.J.: Wiley (The AFP Fund development series).

Dean, D. H.(2003). Consumer perception of corporate donations. Journal of Advertising,32 (4), pp.91-102.

Ellen, P., Webb, D., and Mohr, L. (2006) 'Building corporate associations: Consumer attributions for corporate socially responsible programs. Journal of the Academy of Marketing Science, 34(2), pp.147-57.

Flores, W., Chen, J.C.V. and Ross, W. H. (2014). 'The effect of variations in banner ad, type of product, website context, and language of advertising on Internet users' attitudes' Computers in Human Behaviour,31 (1), pp. 37-47

Friedstad, M., \& Wright, P. (1994). The persuasion knowledge model: How people cope with persuasion attempts. Journal of Consumer Research, 1 pp. 21, 1-31.

Grau, S. L. and Folse, J.A.G. (2007) Cause-Related Marketing (CRM): The influence of donation proximity and message-framing cues on the less-involved consumer'Journal of Advertising, 36(4), pp.19-33.

Hajjat, M. M. (2003) "Effect of Cause-Related Marketing on Attitudes and Purchase Intentions: The Moderating Role of Cause Involvement and Donation Size," Journal of Non-profit\& Public Sector Marketing, 11(1), pp. 93-109.

Hsu, J. C. (1996). Multiple comparisons: Theory and methods. Boca Raton, FL: CRC Press.

Hwang, J., Yoon, Y.-S. and Park, N.-H. (2011) "Structural Effects of Cognitive and Affective Reponses to Web Advertisements, Website and Brand Attitudes, and Purchase Intentions: The Case of Casual-Dining Restaurants," International Journal of Hospitality Management, 30(4), pp.897-907.

Hyllegard, K. H., Yan, R.-N., Ogle, J. P. And Attmann, J..(2010). The influence of gender, social cause, charitable support, and message appeal on Gen Y's responses to cause-related marketing. Journal of Marketing Management,27 (1/2), pp.100-123. 
Judd, C. M., McClelland, G. H., \& Ryan, C. S. (2009). Data analysis: A model comparison approach (2nd ed.). Hove, England: Routledge.

Koschate-Fischer, N., Stefan, I. V. and Hoyer, W. D. (2012) 'Willingness to pay for cause- related marketing: the impact of donation amount and moderating effects. Journal of Marketing Research (JMR), 49 (6), pp. 910-927.

Kotler, P., Hessekiel, D. and Lee, N. (2012) Good works : marketing and corporate initiatives that build a better world-- and the bottom line. Hoboken, N.J.: Wiley.

Kuo, A., \& Rice, D. H. (2015). The impact of perceptual congruence on the effectiveness ofcause-related marketing campaigns. Journal of Consumer Psychology, 25(1), pp.78-88.

Laerd Statistics (2018). ANCOVA test using SPSS Statistics. Statistical tutorials and software guides. Retrieved from https://statistics.laerd.com/. Accessed 16 May 2020

Lafferty, B. A, Goldsmith, R. E, \&Hult, G. Tomas M. (2004). The impact of the alliance on the partners: a look at cause-brand alliances. Psychology and Marketing, 21(7), pp.509-531.

Lafferty, B. A., Lueth, A. K. and McCafferty, R. (2016) “An Evolutionary Process Model of Cause-Related Marketing and Systematic Review of the Empirical Literature," Psychology \& Marketing, 33(11), pp. 951-970.

Liston-Heyes, C., \& Liu, G. (2013). A study of non-profit organisations in causerelated marketing: Stakeholder concerns and safeguarding strategies. European Journal of Marketing, 47(11/12), pp.1954-1974

Mackenzie, S.B., Lutz, R.J., and Belch, G.E. (1986) The role of attitude toward the ad as a mediator of advertising effectiveness: A test of competing explanations, Journal of Marketing Research (JMR), 23(2), pp.130-143.

Meenaghan, J.A. (1983) Commercial sponsorship. European Journal of Marketing, 17(7), pp.5-71.

Meenaghan, T. (2001) Sponsorship and advertising: a comparison of consumer perceptions. Psychology\& Marketing, 18, pp.191-215.

Moosmayer, D., and Fuljahn, A. (2013) 'Corporate motive and fit in cause related marketing', Journal of Product and Brand Management, 22(3), pp.200-207.

Muehling, D. D., Laczniak, R. N. and Andrews, J. C. (1993) Defining, Operationalizing, and Using Involvement in Advertising Research: A Review. Journal of Current Issues and Research in Advertising, 15(1), p.21-57

Muller, S. S., Fries, A. J. and Gedenk, K. (2014) 'How much to give? - The effect of donation size on tactical and strategic success in cause-related marketing'. International Journal of Research in Marketing, 31(2), pp.178-191.

Nunnally, J. C. (1978) Psychometric theory. 2nd ed. New York; London: McGraw-Hill.

Petty, R. Cacioppo, J. and Schumann, D. (1983) 'Central and peripheral routes to advertising effectiveness: The moderating role of involvement', Journal of Consumer Research, 10(2), pp.135-146. 
Polonsky, M. J. and Speed, R. (2001) 'Linking sponsorship and cause-related marketing', European Journal of Marketing, 35 (11/12), pp.1361-1385.

Pracejus, J. W. and Olsen, G. D. (2003) 'The Role of Brand/Cause Fit in the Effectiveness of Cause-Related Marketing Campaigns', Advances in Consumer Research, 30(1), pp.381-381.

Pracejus, J. W. and Olsen, G. D. (2004) 'The role of brand/cause fit in the effectiveness of cause-related marketing campaigns', Journal of Business Research, 57, pp.635-640.

Rieger, D., Bartz, F. and Bente, G.(2015) 'Reintegrating the ad: Effects of context congruency banner advertising in hybrid media', Journal of Media Psychology: Theories, Methods, and Applications, 27(2), pp.64-77.

Robinson, S. R., Irmak, C. and Jayachandran, S. (2012) "Choice of Cause in CauseRelated Marketing,” Journal of Marketing, 76(4), pp. 126-139.

Ross, J., L. Patterson, and M. Stutts.(1992). Consumer perceptions of organizations that use cause-related marketing. Journal of the Academy of Marketing Science 20(1), pp. 93-97.

Segev, S., Wang, W. and Fernandes, J. (2014) 'The effects of ad-context congruency on responses to advertising in blogs: Exploring the role of issue involvement', International Journal of Advertising, 33(1), pp.17-36.

Simmons, C. J. and Becker-Olsen, K. L. (2006) "Achieving Marketing Objectives through Social Sponsorships,” Journal of Marketing, 70(4), pp. 154-169

Strahilevitz, M., (1999). The Effects of Product Type and Donation Magnitude on Willingness to Pay More for a Charity-Linked Brand, Journal of Consumer Psychology, 8(3),pp.215-241.

Tutaj, K. and van Reijmersdal, E. A..(2012). Effects of online advertising format and persuasion knowledge on audience reactions. Journal of Marketing Communications, 18 (1), pp.5-18.

Varadarajan, P. R. and Menon, A. (1988) 'Cause-Related Marketing: A Coalignment of Marketing Strategy and Corporate Philanthropy', Journal of Marketing, 52(3), pp.58-74.

Videras, Julio R. and Ann L. Owen (2006), "Public Goods Provision and Well-Being: Empirical Evidence Consistent with the Warm Glow Theory," B.E. Journal of Economic Analysis \& Policy: Contributions to Economic Analysis \& Policy, 5 (1), pp.1-40.

Wilcox, R. (2012). Modern statistics for the social and behavioural sciences: A practical introduction. Boca Raton, FL: CRC Press

Wilson, N 2017, Online Cause-Related Marketing: The Impact of Donation Amount and Congruence on Consumers' Response, $\mathrm{PhD}$ thesis, Bournemouth University, viewed 22 May 2020 .http://eprints.bournemouth.ac.uk/29865/1/WILSON\%2C\%20Ndasi_Ph.D._2017 .pdf 
Yi, Y. (1993) 'Contextual priming effects in print advertisements: the moderating role of prior knowledge', Journal of Advertising, 22(1), pp.1-10

Zajonc, R.B., Markus, H., (1982). Affective and cognitive factors in preferences. Journal of Consumer Research 9 (2), pp.123-131. 


\section{Appendix1a}
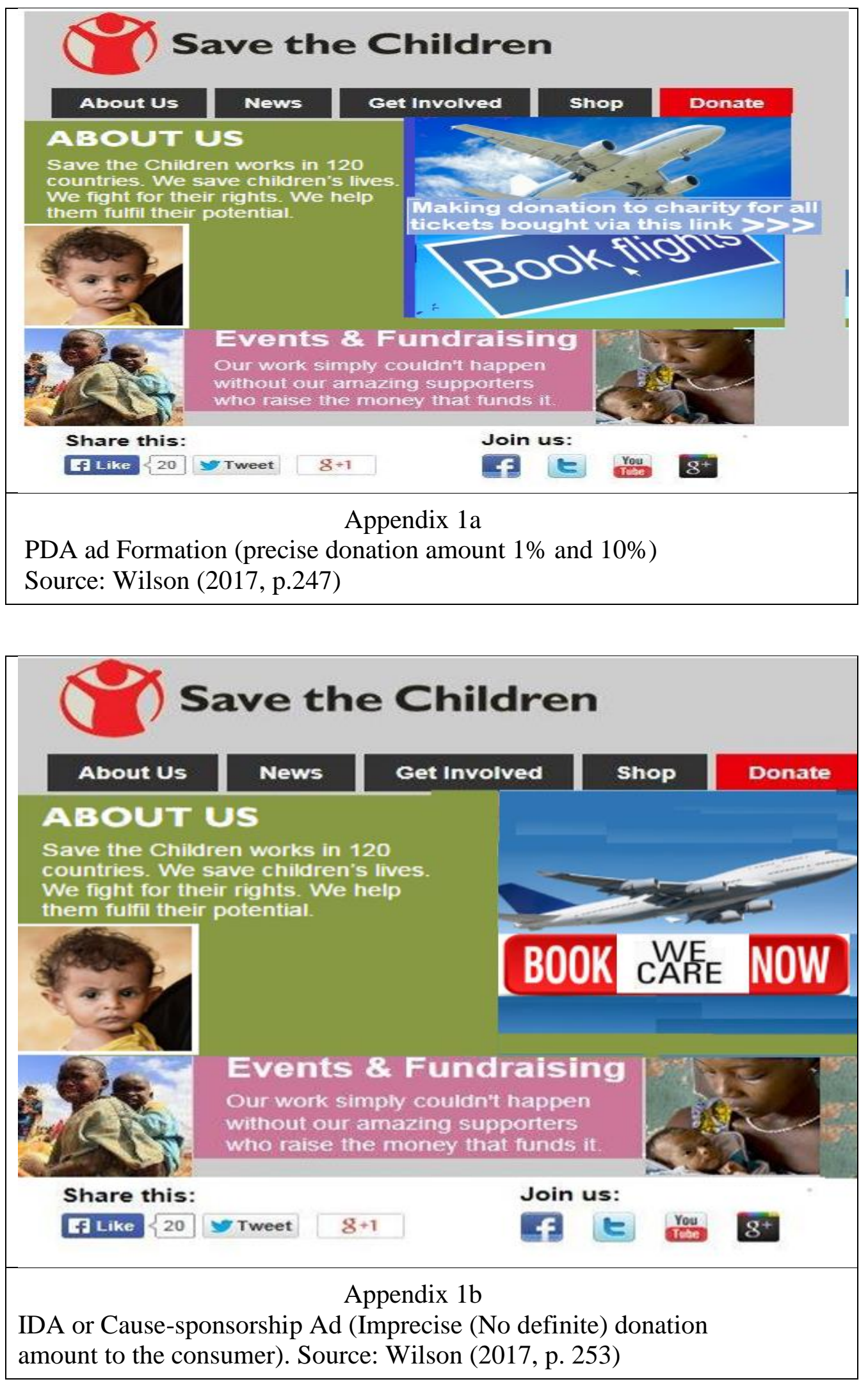
Appendix 2

: Scale Items for Construct Measures

\begin{tabular}{|l|l|l|l|}
\hline & Scale Items & $\begin{array}{l}\text { Coefficient } \\
\text { Alpha }\end{array}$ & $\begin{array}{l}\text { Selected } \\
\text { Sources }\end{array}$ \\
\hline $\begin{array}{l}\text { Perceived } \\
\text { Lonation } \\
\text { Level }\end{array}$ & $\begin{array}{l}\text { A [\%] donation is in this situation a low vs. high } \\
\text { amount; a [\%] donation is in this situation a } \\
\text { below average vs. above average amount; a [\%] } \\
\text { donation is in this situation a below a small vs. a } \\
\text { large amount. }\end{array}$ & $\begin{array}{l}\text { Koschateet al. } \\
\text { (2012) }\end{array}$ \\
\hline $\begin{array}{l}\text { Attitudes } \\
\text { towards Ad }\end{array}$ & $\begin{array}{l}\text { Making a purchase via the Ad link is a } \\
\text { good way to raise funds online; The Ad } \\
\text { is a good way to support a NPO cause } \\
\text { online; It is a convenient way to support } \\
\text { a NPO cause online; It is a good way to } \\
\text { shop online }\end{array}$ & 0.91 & $\begin{array}{l}\text { Mackenzie and } \\
\text { Lutz (1986). }\end{array}$ \\
\hline $\begin{array}{l}\text { Purchase } \\
\text { Intention }\end{array}$ & $\begin{array}{l}\text { very likely vs. unlikely; very improbable } \\
\text { vs, very probable; very impossible vs. } \\
\text { very possible }\end{array}$ & 0.90 & Yi (1993). \\
\hline $\begin{array}{l}\text { Cause- } \\
\text { Involvement unimportant cause to me vs. Is an } \\
\text { important cause to me; Means nothing to } \\
\text { me vs. Means a lot to me; Is personally } \\
\text { irrelevant to me vs. Is personally relevant } \\
\text { to me }\end{array}$ & 0.71 & $\begin{array}{l}\text { Grau and } \\
\text { Folse (2007) }\end{array}$ \\
\hline
\end{tabular}

Figure 1. The conceptual model for the impact of IDA and PDA CRM Internet Ad Frames

Display Ad Format(IV) Feedback(DV) covariate

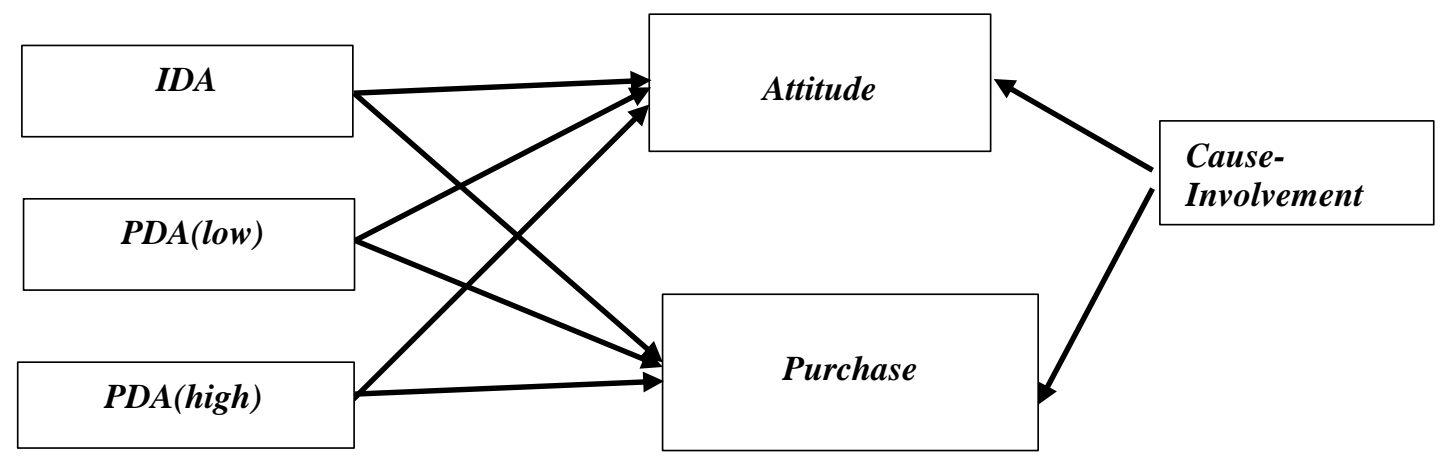




\begin{tabular}{|c|c|c|c|c|c|c|}
\hline \multicolumn{7}{|c|}{ Table 1: Summary of Hypotheses Testing } \\
\hline \multirow[t]{2}{*}{ Ad Frame } & \multirow[t]{2}{*}{$\begin{array}{c}\text { Mean } \\
\text { Difference }\end{array}$} & \multirow[t]{2}{*}{$\mathrm{SE}$} & \multirow[t]{2}{*}{ Sig. } & \multicolumn{2}{|c|}{$\begin{array}{c}95 \% \text { Confidence } \\
\text { Interval for } \\
\text { Difference }^{\mathrm{b}}\end{array}$} & \multirow[t]{2}{*}{ Hypothesis } \\
\hline & & & & $\begin{array}{l}\text { Lower } \\
\text { Bound }\end{array}$ & $\begin{array}{l}\text { Upper } \\
\text { Bound }\end{array}$ & \\
\hline & \multicolumn{5}{|c|}{ Dependent Variable: Attitudes towards the AD } & \\
\hline $\begin{array}{l}\text { EDA(low) vs } \\
\text { IDA }\end{array}$ & 0.128 & 0.115 & 0.805 & -0.149 & 0.404 & $\mathrm{H} 1 \mathrm{a}-\mathrm{n} / \mathrm{s}$ \\
\hline $\begin{array}{l}\text { EDA(high) vs } \\
\text { IDA }\end{array}$ & 0.155 & 0.115 & 0.531 & -0.121 & 0.431 & $\mathrm{H} 1 \mathrm{~b} \mathrm{n} / \mathrm{s}$ \\
\hline \multirow{2}{*}{$\begin{array}{l}\text { EDA(high) vs } \\
\text { EDA(low) }\end{array}$} & 0.028 & 0.112 & 1.000 & -0.241 & 0.297 & $\mathrm{H} 1 \mathrm{c}-\mathrm{n} / \mathrm{s}$ \\
\hline & \multicolumn{5}{|c|}{ Dependent Variable: Purchase Intention } & \\
\hline $\begin{array}{l}\text { EDA(low) vs } \\
\text { IDA }\end{array}$ & $0.578^{*}$ & 0.143 & 0.000 & 0.235 & 0.922 & $\mathrm{H} 2 \mathrm{a}-\mathrm{s}$ \\
\hline $\begin{array}{l}\text { EDA(high) vs } \\
\text { IDA }\end{array}$ & $0.947^{*}$ & 0.143 & 0.000 & 0.604 & 1.290 & $\mathrm{H} 2 \mathrm{~b}-\mathrm{s}$ \\
\hline $\begin{array}{l}\text { EDA(high) vs } \\
\text { EDA(low) }\end{array}$ & $0.368^{*}$ & 0.139 & 0.025 & 0.034 & 0.703 & $\mathrm{H} 2 \mathrm{c}-\mathrm{s}$ \\
\hline
\end{tabular}

Figure 2: Attitude towards the Ad as a Function of Perceived Donation Amount

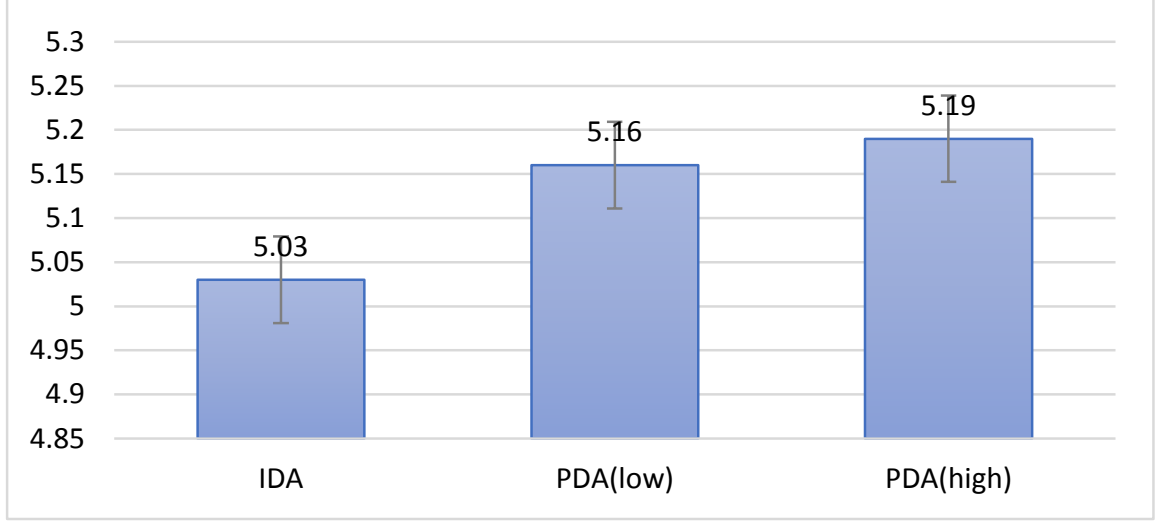


Figure 3: Purchase Intention for Ad as a Function of Perceived Donation Amount

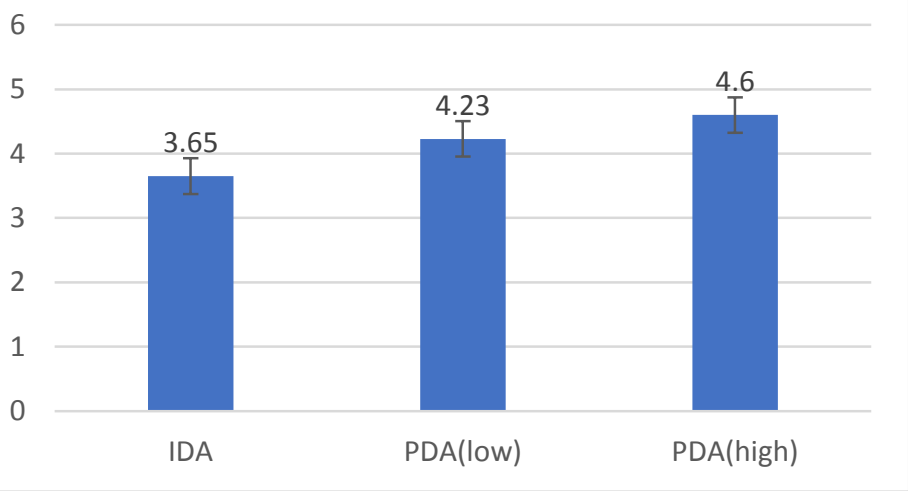

